\title{
Market potential for certified forest (wood) products in Ontario, Canada
}

\author{
by Maria C. Spinazze ${ }^{1}$ and Shashi Kant ${ }^{2}$
}

This study, conducted in the fall of 1997, documents: i) consumer perceptions regarding environmental marketing; ii) consumer willingness to purchase certified forest (wood) products and to pay a premium for such products; iii) variations in premium across products and prices; and, iv) levels of awareness and acceptance of certification within the forest industry. Analysis indicates that Ontario consumers are environmentally conscious. The mean response of consumers indicates that they are willing to pay a $10 \%$ premium for nearly all certified products. In some cases, premium varies with the price of certified products; lowprice furniture items command a higher premium than do highprice furniture products. Approximately $90 \%$ of consumers prefer to purchase certified furniture and lumber products over non-certified, and $73 \%$ of consumers prefer to purchase recycled paper products over certified paper products. Generally, awareness and acceptance of certification among primary producers and re- manufacturers are low. Only $39 \%$ of respondents indicate a willingness to pay a $10 \%$ premium for certified products, but almost all respondents are willing to purchase certified forest products if all other aspects, such as price and quality, are equal. Separation of certified and non-certified wood and wood products may pose a problem for many companies.

Key words: forest certification premium, green premium, market segmentation, niche markets
Cette etude, entreprise a l'automne 1997, etablit: i) les perceptions des consommateurs par rapport au marketing environnemental; ii) l'interet des consommateurs a se procurer des produits forestiers (bois) certifies et a payer une prime pour de tels produits; iii) les variations au niveau des primes entre les produits et les prix; et, iv) le niveau de sensibilisation et d'accueil face a la certification au sein de l'industrie forestiere. L'analyse demontre que les consommateurs de l'Ontario sont conscients de l'importance de l'environnement. La reponse moyenne des consommateurs indique qu'ils sont pret a payer une prime de $10 \%$ pour la plupart des produits certifies. Dans certains cas, la prime varie selon le prix des produits certifies; les biens bon marche entrainent une prime plus elevee que les biens dispendieux. Environ $90 \%$ des consommateurs preferent acheter des biens et des produits du sciage certifies plutot que non certifies, et $73 \%$ des consommateurs preferent acheter des produits de papier recycle plutot que des produits de papier certifie. Generalement, la sensibilisation et l'accueil de la sensibilisation parmi les producteurs primaires et les manufacturiers de produits secondaires sont faibles. Seulement $39 \%$ des repondants ont indique qu'ils etaient pret a acheter des produits forestiers certifies si tous les autres aspects, comme le prix et la qualite etaient egaux. La division entre les produits forestiers ou de bois certifies et les produits forestiers ou de bois non certifies pourrait etre un probleme pour plusieurs entreprises.

Mots-cles: prime de certification forestiere, prime verte, segmentation du marche, niches du marche

\section{Introduction}

Consumer awareness of environmental issues is an ever-increasing phenomenon. As education of today's younger generation regarding environmental concerns reaches higher levels, a different consumer perspective is evolving (Shrum et al. 1995). Concern about the environment is so great that environmentalism has been designated as potentially "the biggest business issue of the 1990s" (Kirkpatrick 1990). Affecting this increased wave of interest is the realisation that natural resources are of a finite nature and that the ecological balance can be easily disrupted. Specifically, forests and forestry-based issues have held the spotlight in this decade and have become world-wide concerns since the UN Conference on Environment and Development (UNCED) in 1992. Although the dialogue has been primarily between special interest groups, scientists, and industry, the general public has also become concerned about forestry issues.

In response to these forestry concerns, national governments, environmental organisations, and the forest products indus-

\footnotetext{
${ }^{1}$ Sales and Marketing, Timberlane Dimension and Components, Toronto, Ontario. ${ }^{2}$ Faculty of Forestry, University of Toronto, 33 Willcocks Street, Toronto, Ontario, M5S 3B3.
}

try have developed standards of sustainable forest management practices. In many cases, upgrading traditional forest management practices to sustainable management practices involves an added cost. Hence, a challenge to agencies involved in sustainable forest management practices is to accommodate this extra cost without a major adverse impact on their share in the market. One way of dealing with this challenge may be to pass the additional costs to the consumer through appropriate marketing strategies such as "environmental" or "green" marketing to redirect consumer demand to environmentally preferable products and services (Coddington 1993). Lessons from other industries show that firms who take the lead and cater to the "green" market segment have

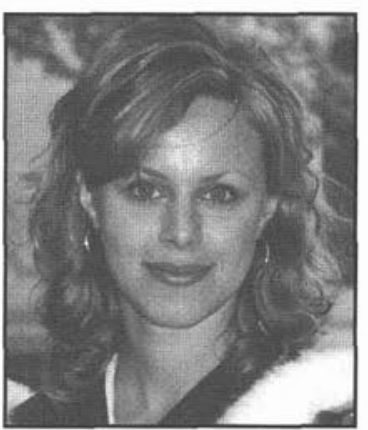

Maria Spinazze

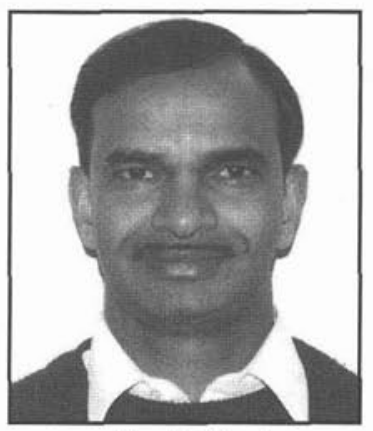

Shashi Kant 
found the endeavour to be profitable (Leslie 1990). Environmentally conscious citizens appear to be willing to change their buying behaviours so as to improve the environment (Chase 1991); however, there is growing scepticism by consumers regarding environmental claims made by companies (Zinkhan and Carlson 1995).

Credibility is key to successfully implementing an environmental marketing strategy. Third-party certification is probably the most credible assurance to the general public that the forests from which products are derived are being managed according to the principles of sustainability. Third party forest certification is developing at a rapid rate. In the case of forest certification, it is believed that niche markets already exist (Lyke 1994, Mater 1995).

In Canada, two systems of certification are in operation: the Forest Stewardship Council's (FSC) ${ }^{3}$ performance based system and the Canadian Standards Associations (CSA) ${ }^{4}$ forest management system (Elliott and Hackman 1996). The FSC system, being an international system, may attract forestry firms looking for international markets.

The subject of forest certification is relatively new, and only a few studies on the topic have been published. Consumer research in Britain by World Wide Fund for Nature (WWF 1996) indicates that 66 percent of consumers are willing to pay up to a 13.6 percent premium for certified wood furniture products. Winterhalter and Cassens (1993) report that 81 percent of US consumers, with an income of $\$ 50000$ or more, are willing to pay a premium ranging from 1 to 20 percent for certified wood furniture products. Ozanne and Vlosky (1997), surveying US homeowners, report that willingness to pay premiums for certified forest products varied depending on the product. Products included in their survey were a $2 \times 4-8^{\prime}$ stud (priced at $\$ 1$ ), a ready-to-assemble chair (priced at $\$ 100$ ), a dining room set (priced at $\$ 1000$ ), a kitchen remodelling job (priced at $\$ 5000$ ), and a new home (priced at $\$ 100000$ ). Of their consumer respondents, 63 percent reported they were willing to pay more for certified products, and the premium ranged from $4.4 \%$ for a new home to $18.7 \%$ percent for a $\$ 1$ stud. The results indicated that as product price increased, fewer respondents were willing to incur a premium, and fewer respondents were willing to incur higher premiums. Ozanne and Smith (1995) describe the market segment most likely to seek out and buy certified forest products as being politically liberal, democratic, female, member of an environmental organisation, and fairly well-educated. This profile has been confirmed by Ozanne and Vlosky (1997) who found the

\footnotetext{
${ }^{3}$ The FSC supports environmentally appropriate, socially beneficial, and economically viable management of the world's forests. FSC-accredited certification is performance-based. The ten principles and criteria for forest management outlined by the FSC are designed to assure that consistent performance-based standards are used in evaluating forest management practices by accredited certifiers. The method of communicating to consumers that conformance to standards has been met is through an ecolabel placed directly on wood products. (Upton and Bass 1996).

${ }^{4}$ The CSA is a national standards writing organization. A management system approach has been taken with regard to registration by the "Sustainable Forest Management" project that is modeled on the ISO 14001 Environmental Management System. A certificate is issued if the SFM system is in place and operating satisfactorily; however, no chain of custody provision is made therefore, a label may not be used at the point of purchase (Elliot and Hackman 1996).
}

most likely segment of the population for certified wood products to be members of both the Democratic Party and an environmental organisation, female and politically liberal.

One study, on the producer end of market analysis, by The Institute for Sustainable Forestry (Mater 1995) exists, and it covers three U.S. states - Washington, Oregon, and California. The main findings of the study are: $50 \%$ of all businesses surveyed are aware of certification; over 80 percent of businesses are willing to handle certified products given equivalent price and quality indicating a strong market demand for certified wood products which do not carry any premium; 54 percent of businesses are willing to pay a 10 percent premium if that premium could be passed on to consumers.

At present, no studies are available on the response of either Canadian consumers or producers to forest certification. The Canadian forest industry may make use of U.S. and European studies for the export market, but a study of Canadian consumers is necessary in order to understand responses of domestic markets. Similarly, an understanding of the level of awareness and acceptance of certification by producers is also necessary in order to assess whether certified products will make it to the consumer. The available studies also lack a comprehensive analysis for any one given geographic area. All studies focus on one or a few product types, and only one study looks at the impact of product prices on the consumer's willingness to pay. The studies are also either broad in their selection of consumer respondents or too specific, e.g., homeowners or consumers having a salary greater than $\$ 50000$. We attempt to improve over the existing studies in many ways.

Our study consists of both consumer and producer surveys in the province of Ontario. The study is unique in the selection of consumer respondents; only active buyers of wood products are selected from the general public who are not specific to any socioeconomic or demographic character. The study covers three types of products, namely wood furniture, lumber and wood flooring, and paper products. The impact of product prices on the consumers' willingness to pay a certification premium is explored. The focus of the study is on FSC certification. However, the study is preliminary and of a small scale. The consumer sample is from the Greater Toronto area in which only $38 \%$ of Ontario's population and $14 \%$ of Canada's population resides. Hence, results presented in this paper cannot be generalised to Canadian consumers as a whole. However, it is a pioneer study in certified forest products in Canada, and provides basic primary information to forest managers, forestry firms, and other agencies involved in forest certification.

The study has the following objectives: (i) to identify consumers' and producers' awareness of sustainable forest management and certification of forest products; (ii) to assess the willingness to pay a premium for certified wood products by Ontario consumers over a range of wood products and their prices; and, (iii) to profile those consumers who are willing to pay the highest certification premium.

The methods used in the consumer and the producer surveys are presented below. Thereafter, results of both surveys are discussed. Finally, conclusions are drawn and recommendations are made for future research.

\section{Methods}

Two surveys, designed for consumers and producers, are discussed separately. 


\section{Consumer survey}

The consumer survey comprises consumer attitudes and perceptions towards forest management, forest certification, and certified forest products; and consumers' willingness to pay (WTP) a premium for certified forest products. Willingness to pay a premium for certified forest products is measured by the Contingent Valuation (CV) method. Although the CV method has been criticised as not necessarily reflecting actual consumer preferences (Mitchell and Carson 1989), CV studies have been done for a large number of environmental issues such as air quality, recreational value of parks, and the preservation of wildlife, etc. (Field 1994). In Canada, due to the lack of certified forests and certified forest products in the marketplace currently, a study examining actual consumer behaviour is not possible. Hence, the CV method is the only option. Furthermore, this approach is preferred in order to be consistent and comparable to other studies of certified forest products from the U.S. and Europe.

The consumer survey consists of two sections. The first section pertains to the socioeconomic and demographic variables of the respondent, such as age, gender, marital status, education, occupation, annual income, and political affiliation. The second section pertains to forest management and forest certification, and contains four sub-sections. The first sub-section - forest management in Canada - includes items on the state of forest management, factors responsible for the current state of forests, and respondent's knowledge of sustainable forest management. The second sub-section - environmental concerns - includes items on membership of environmental groups, environmental concerns, and environmental information and labelling. The third sub-section - forest certification and credibility - incorporates items on awareness of forest certification, the Forest Stewardship Council, and other environmental organisations, and on the credibility of certification by different organisations. In these three sub-sections, respondents are asked to respond either in the terms of yes/no or on a scale that varies from 1 (strongly agree) to 5 (strongly disagree). The final sub-section probes consumers' preferences to buying certified products and willingness to pay a premium for those products. Wood products included in this section are: furniture (wooden table) ranging in price from $\$ 100$ to $\$ 1000$; lumber priced at $\$ 1.5$ and $\$ 3.00$ / per standard $2 \times 4$ lumber; hardwood flooring at $\$ 4.00$ and $\$ 6.00$ per square feet; and paper products (photocopy paper, high quality laser paper, letterhead paper, newspaper, and paperback book) ranging from $\$ 1.00$ to $\$ 20.00$ per item. The survey was pre-tested four times, and necessary changes were made to improve clarity, simplicity, and the length of questionnaire.

In the choice of sample respondents, it is important to focus on consumers who are actively participating in the wood product's market as opposed to random consumers who may never purchase wood products themselves and, therefore, their response may not reflect actual market demand. Hence, sample respondents were randomly selected from consumers visiting IKEA, Home Depot, Office Depot, and Home Hardware in the Greater Toronto area to purchase wood products. The wood products included in the survey governed the choice of the indicated market outlets. The survey was designed with a return addressed and stamped cover so the survey could be filled out at the consumers' convenience and then returned to the researchers by mail (Dillman 1978).

\section{Producer/re-manufacturer survey}

The producer/re-manufacturer survey is shorter than that of the consumer survey. The survey has two parts. The first part is the company's background, and includes items on name of company, number of employees, production capacity of company in FBM (Foot Board Measure), products and tree species used. The second part is concerned with certification, and contains items on: awareness of forest certification, awareness of the Forest Stewardship Council, purchase of raw material from certified forests, payment or willingness to pay a premium for wood from certified forests, interest in a chain-of-custody tracking system, and the sale of certified forest products.

In this survey, respondents were first contacted by telephone, and a short conversation about the nature of the survey and its purpose was held. Subsequently, the survey was faxed to respondents. After a two-week duration, a follow up "reminder" phone call was made if the survey response had not been received by that point.

\section{Results and Discussion}

The consumer survey response rate is $21.2 \%$ (106 respondents). Seventy-three fully completed responses are used in the analysis. Male respondents (59\%) outnumber female respondents $(41 \%)$. Ninety-nine percent of the respondents are Canadian citizens; of these, $81 \%$ are born in Canada, $2 \%$ in the U.S., $13 \%$ in Europe and $4 \%$ elsewhere. A high percentage $(73 \%)$ of the respondents have a university degree while $27 \%$ respondents have a high school or college level education. The number of single respondents $(48 \%)$ is almost equal to married respondents (44\%), while only $4 \%$ are divorced and $3 \%$ widowed. By age group, $37 \%$ are younger than 30 years, $19 \%$ are between the age of 31 and 40 years, $21 \%$ between 41 and 50 years, and $23 \%$ over 50 years. In terms of income groups, $29 \%$ earn less than $\$ 30000$ annually, 15\% earn between $\$ 30000$ and $\$ 39000,16 \%$ earn between $\$ 40000$ and $\$ 49000$, $16 \%$ earn between $\$ 50000$ to $\$ 69000$, and the remaining, $24 \%$ earn more than $\$ 70000$ per year. Only $49 \%$ of respondents own their own home.

Due to the low response rate, results are subject to response statistical bias, and users of these results should keep this limitation in view. However, we do not think that responses are biased by the members of any group such as environmental groups because only $17.8 \%$ respondents are members of environmental groups. In addition, the results of analysis for five clusters of members and non-members of environmental groups, each cluster representing a different environmental preference, range from very low to high, are also included in the paper. The sample is also well representative of male and females, income groups, age groups, marital status, and people born in different countries. But, in true sense, all consumer surveys are subject to self-select response outcomes, because only willing consumers respond to survey questions. Hence, consumer surveys are not to be seen as definitive but are to be used appropriately and wisely. The same is the case with the results of this study.

\section{Consumers' attitude and perceptions}

The results of consumer responses to forest management, environmental concerns, and forest certification are given in Tables $1 \mathrm{a}$ and $1 \mathrm{~b}$. The level of satisfaction with forest management in Canada is low with timber harvesting being 
Table 1a. Summary of consumer opinions on forest management, environmental concerns, and forest certification. Questions rated on a scale of 1 to 5 . (The number of respondents $=73$ )

\begin{tabular}{|c|c|c|c|c|c|c|}
\hline \multirow[b]{2}{*}{ Question } & \multicolumn{5}{|c|}{ Response Frequency (in percentage) } & \multirow[b]{2}{*}{ Mean } \\
\hline & 1 & 2 & 3 & 4 & 5 & \\
\hline \multicolumn{7}{|l|}{ Forest Management } \\
\hline Q1a: Satisfaction with forest management in Ontario & 1.4 & 6.8 & 27.4 & 42.5 & 21.9 & 3.77 \\
\hline \multirow{2}{*}{\multicolumn{7}{|c|}{$\begin{array}{l}\text { Q1b: Factors responsible for the current state of forests } \\
\text { in Ontario }\end{array}$}} \\
\hline a: environmental pollution by industry & 21.9 & 31.5 & 24.7 & & & \\
\hline b: timber harvesting & 35.6 & 3.9 & 13.7 & 4.1 & 13.7 & 2.27 \\
\hline c: land clearing for agriculture & 11.0 & 27.4 & 27.4 & 30.1 & 4.1 & 2.89 \\
\hline $\mathrm{d}$ : tourism and recreation & 5.5 & 16.4 & 28.8 & 39.7 & 9.6 & 3.32 \\
\hline e: construction and urban sprawl & 30.1 & 15.1 & 27.4 & 21.9 & 5.5 & 2.58 \\
\hline f: natural catastrophes & 9.6 & 11.0 & 21.9 & 35.6 & 21.9 & 3.49 \\
\hline Q1d: How sustainably are forests managed in Canada & 4.1 & 8.2 & 28.8 & 42.5 & 16.4 & 3.59 \\
\hline \multicolumn{7}{|l|}{ Environmental Concerns } \\
\hline \multicolumn{7}{|l|}{ Q2b: Opinion on statements } \\
\hline a: do what is good for environment even if it costs more & 30.1 & 50.7 & 12.3 & 6.8 & 0.0 & 1.96 \\
\hline $\begin{array}{l}\text { b: concern over the state of environment for future } \\
\text { generations }\end{array}$ & 61.6 & 20.5 & 11.0 & 5.5 & 1.4 & 1.64 \\
\hline c: environmental problems are less urgent than claimed & 5.5 & 9.6 & 2.7 & 37.0 & 45.2 & 4.07 \\
\hline \multicolumn{7}{|l|}{ Q2c: Opinion on environmental labeling } \\
\hline a: sufficient information on products & 4.1 & 23.3 & 20.5 & 28.8 & 23.3 & 3.43 \\
\hline b: labels are not trustworthy & 19.2 & 35.6 & 31.5 & 11.0 & 2.7 & 2.42 \\
\hline c: variety of labels is confusing & 20.5 & 31.5 & 28.8 & 16.4 & 2.7 & 2.49 \\
\hline $\mathrm{d}$ : environmental information is clear and understandable & 1.4 & 26.0 & 31.5 & 34.2 & 6.8 & 3.19 \\
\hline e: one of the most important aspects of production & 30.1 & 37.0 & 23.0 & 7.0 & 2.7 & 2.15 \\
\hline \multirow{2}{*}{\multicolumn{7}{|c|}{$\begin{array}{l}\text { Forest Certification } \\
\text { Q3f: Credibility of certificate of sustainable management } \\
\text { given by the following organizations: }\end{array}$}} \\
\hline & & & & & & \\
\hline a: interest group of forest/timber industry & 11.0 & 8.2 & 19.2 & 32.9 & 28.8 & 3.6 \\
\hline b: international environmental pressure groups & 38.4 & 38.4 & 9.6 & 6.8 & 6.8 & 2.05 \\
\hline c: Ministry of Natural Resources & 16.4 & 37.0 & 19.2 & 12.3 & 15.1 & 2.73 \\
\hline $\mathrm{d}$ : manufacturers of wood products & 4.1 & 9.6 & 24.7 & 31.5 & 30.1 & 3.74 \\
\hline e: Forest Stewardship Council & 9.6 & 31.5 & 50.7 & 2.7 & 5.5 & 2.63 \\
\hline \multicolumn{7}{|l|}{$\begin{array}{l}\text { Q4a: Importance of wood originating from sustainably } \\
\text { managed forest for }\end{array}$} \\
\hline a: furniture & 42.5 & 32.9 & 17.8 & 4.1 & 2.7 & 1.92 \\
\hline$b$ : fixtures & 47.9 & 31.5 & 17.8 & 2.7 & 0.0 & 1.75 \\
\hline c: paper products & 63.0 & 21.9 & 11.0 & 4.1 & 0.0 & 1.56 \\
\hline
\end{tabular}

indicated as a major contributor to the current state of forests. Consumers are concerned over the state of the environment and indicate that they are willing to do what is good for the environment even if this course of action is more costly. With respect to environmental labelling, consumers may be confused by the variety of different certification labels and unclear about the type of information they contain. However, environmental-labels are still an important aspect of production. Canadian consumers of wood product are aware of environmental issues and concerned about the origin of raw material for wood products.

Although most consumers had not heard of the FSC prior to the survey, in general, their credibility rating is higher than for interest groups of the timber industry. The fact that environmental pressure groups, such as WWF, are given a high credibility rating could be a marketing advantage for the FSC certification as it is endorsed by WWF.

\section{Premium for certified wood products across products and prices}

The results of consumers' willingness to pay a premium for certified wood products are given in Table 2 . The table gives
Table 1b. Summary of consumer opinions on forest management, environmental concerns, and forest certification. Questions answered 'yes' or 'no'. (The number of respondents $=73$ )

\begin{tabular}{|c|c|}
\hline $\begin{array}{r}\text { Perc } \\
\text { respor } \\
\text { answ } \\
\end{array}$ & $\begin{array}{l}\text { entage of } \\
\text { idents who } \\
\text { ered 'yes' }\end{array}$ \\
\hline \multicolumn{2}{|l|}{ Forest management } \\
\hline Q1c1: Have you heard of 'sustainable forest management' & 70 \\
\hline \multicolumn{2}{|l|}{ Environmental concerns } \\
\hline Q2a: Member of an environmental group/organization & 18 \\
\hline \multicolumn{2}{|l|}{ Forest certification } \\
\hline Q3a: Familiar with 'forest management certification' & 19 \\
\hline Q3b: Familiar with the Forest Stewardship Council & 3 \\
\hline Q3c: Familiar with the FSC logo & 7 \\
\hline \multicolumn{2}{|l|}{ Q3e: Familiarity with environmental organizations } \\
\hline i: WWF & 96 \\
\hline ii: Green peace & 100 \\
\hline $\begin{array}{l}\text { Q4ci: Prefer to purchase furniture with certification label } \\
\text { (cost equal) }\end{array}$ & 90 \\
\hline $\begin{array}{l}\text { Q4di: Prefer to purchase flooring with certification label } \\
\text { (cost equal) }\end{array}$ & 90 \\
\hline $\begin{array}{l}\text { Q4ei: Prefer to purchase paper product with certification label } \\
\text { (cost equal) }\end{array}$ & 89 \\
\hline Q4eii: Prefer to purchase labeled paper product over recycled & 27 \\
\hline
\end{tabular}


Table 2. Frequency (in percentage) for willingness to pay premiums for different certified products

Frequency of responses in percentage

\begin{tabular}{|c|c|c|c|c|c|c|c|c|}
\hline \multirow[b]{3}{*}{ Product } & \multirow[b]{3}{*}{ Price } & \multirow{2}{*}{\multicolumn{6}{|c|}{ Premium in percentage of sales price $(\%)$}} & \\
\hline & & & & & & & & \multirow[b]{2}{*}{ Mean } \\
\hline & & $\mathbf{0}$ & 5 & 10 & 15 & 20 & 25 & \\
\hline \multirow[t]{4}{*}{ Furniture (wood table) } & $\$ 100$ & 16.4 & 11.0 & 32.9 & 16.4 & 21.9 & 1.4 & 11.03 \\
\hline & $\$ 200$ & 16.4 & 15.1 & 38.4 & 1.4 & 19.2 & 9.6 & 9.55 \\
\hline & $\$ 500$ & 17.8 & 21.9 & 37.0 & 15.1 & 6.8 & 1.4 & 8.84 \\
\hline & $\$ 1000$ & 19.2 & 21.9 & 37.0 & 12.3 & 6.8 & 1.4 & 8.66 \\
\hline \multirow[t]{2}{*}{ Flooring (\$/square foot) } & $\$ 4$ & 21.9 & 1.4 & 53.4 & 15.1 & 5.5 & 1.4 & 9.32 \\
\hline & $\$ 6$ & 20.5 & 1.4 & 56.2 & 15.1 & 5.5 & 1.4 & 9.93 \\
\hline \multirow[t]{2}{*}{ Lumber (standard $2 \times 4$ ) } & $\$ 1.5$ & 21.9 & 1.4 & 1.4 & 43.8 & 21.9 & 9.6 & 9.79 \\
\hline & $\$ 3$ & 21.9 & 2.8 & 49.3 & 19.2 & 6.8 & 0.0 & 9.29 \\
\hline Photocopy paper & $\$ 2$ & 27.4 & 4.1 & 30.1 & 16.4 & 20.5 & 1.4 & 11.37 \\
\hline Laser paper & $\$ 6$ & 27.4 & 1.4 & 31.5 & 13.7 & 13.7 & 0.0 & 10.09 \\
\hline Letterhead paper & $\$ 10$ & 28.8 & 2.7 & 26.0 & 19.2 & 19.2 & 1.4 & 10.27 \\
\hline Newspaper & $\$ 1$ & 28.8 & 0.0 & 27.0 & 31.5 & 15.1 & 21.9 & 11.16 \\
\hline Paperback book & $\$ 20$ & 28.8 & 5.5 & 34.2 & 17.8 & 12.3 & 0.0 & 8.84 \\
\hline
\end{tabular}

the percentage of respondents who are not willing to pay any premium and who are willing to pay premiums of $5,10,15$, 20 , and $25 \%$ respectively. These percentage values can be used by marketing managers to design market segmentation strategies for certified products. The mean values of premiums for all products are different from zero at the $5 \%$ significance level. The most frequent response of consumers (modal value) to all products except lumber priced at $\$ 1.50$ and newspaper is a $10 \%$ premium. There are variations in premiums that consumers are willing to pay for different products. In the case of furniture and lumber, there is some variation across prices also. The results of premiums paid for furniture (wooden table) priced from $\$ 100$ to $\$ 1000$ indicate a tendency of decreasing certification premium with increase in price up to a certain critical level of price; after the critical price level has been reached, certification premium becomes constant ${ }^{5}$. A similar outcome is observed in the case of lumber. One of the reasons for the decrease in premium with prices up to a certain critical price level may be that in high priced products, other factors such as quality of the product become dominant, and certification becomes secondary; as quality of product improves the importance of certification remains constant. Hence, in the case of furniture and lumber, lower priced products could command a slightly higher premium than more expensive products. Therefore, a niche market in Ontario may exist for some certified furniture and lumber products.

In the case of hardwood flooring and paper products, the mean premium (approximately 10\%) is essentially the same (statistically not different) for all products in the category. Although, consumers have indicated that on an average they would prefer to purchase recycled paper products, many are still willing to incur a $10 \%$ premium for certified paper products. A t-test indicated that there was no difference in the number of respondents

\footnotetext{
${ }^{5}$ The premium of $11.03 \%$ for a wooden table priced at $\$ 100$ is statistically different at the $1 \%$ significance level from premiums of $9.55 \%$ for a table priced at $\$ 200,8.84 \%$ for a table priced at $\$ 500$, and $8.66 \%$ for a table priced at $\$ 1000$. The premium of $9.55 \%$ for a table priced at $\$ 200$ is statistically different at the $10 \%$ significance level from the premium of $8.84 \%$ for a table priced at $\$ 500$. But, the premiums for tables, priced at $\$ 500$ and $\$ 1000$, are not statistically different at the $10 \%$ significance level. The premiums of $9.79 \%$ for lumber priced at $\$ 1.50$ is statistically different from the premium of $9.29 \%$ for lumber priced at $\$ 3.00$ at the $10 \%$ significance level.
}

who would not pay a premium and who would pay $10 \%$. Across all products, an average of $22.86 \%$ of respondents would not pay a premium while $38.56 \%$ would be willing to pay a $10 \%$ premium.

However, market development for certified forest products does not depend only on the consumers' willingness to pay a premium but also on consumers' attitude toward certified products. For both furniture and lumber/flooring products, $90 \%$ of consumers (Table 1b) have responded that, all else being equal, they would prefer to purchase a given forest product with a certification label over a product without such a label. Respondents also indicate that it is important to them that products originate from sustainably managed forests (Table 1a). Certification is a means by which a company can report to the consumer on their good forest practice performance (Lloyd 1993). Therefore, companies who do not realise the "green premium" may benefit from increased market share. Companies in Canada interested in certification could pursue an environmental marketing strategy that may seek to drive demand for certified products up rather than waiting for niche markets to develop.

In the case of the pulp and paper industry, the fact that nearly $73 \%$ of consumers (Table $1 \mathrm{~b}$ ) would prefer to purchase recycled paper products over environmentally certified products may have important implications. The FSC certification system requires chain-of-custody tracking. Therefore, companies are required to keep a record of the origin of their wood products and to separate certified from non-certified timber. These regulations pose a great problem for the many pulp and paper companies who obtain wood, wood products, or pulp from a variety of sources (Zimmer 1995). If it is not impossible for these companies to do this, it would certainly incur a large cost associated with separation. If only $27 \%$ of consumers are willing to purchase certified paper products and an even smaller percentage are willing to pay a $10 \%$ premium, the costs of certification may far exceed the benefits in terms of market share and the "green premium" in the case of pulp and paper products.

\section{Socioeconomic, and demographic variables and premium for certified forest products}

To find out the dependence of premium for certified wood products on socioeconomic and demographic variables, 
Table 3. Certification premium (as percentage of the total price) for wood products by 'Gender' and 'Education'

\begin{tabular}{|c|c|c|c|c|c|c|c|c|c|c|c|c|c|c|}
\hline \multirow{2}{*}{ Willingness to pay } & & \multicolumn{4}{|c|}{ Furniture } & \multicolumn{4}{|c|}{ Flooring/lumber } & \multicolumn{5}{|c|}{ Paper products } \\
\hline & & $\$ 100$ & $\$ 200$ & $\$ 500$ & $\$ 1000$ & $\$ 4$ & $\$ 6$ & $\$ 1.5$ & $\$ 3$ & $\$ 2$ & $\$ 6$ & $\$ 10$ & $\$ 1$ & $\$ 20$ \\
\hline Overall $(n=73)$ & $\%$ & 11.03 & 9.55 & 8.84 & 8.66 & 9.32 & 9.93 & 9.79 & 9.29 & 11.37 & 10.09 & 10.27 & 11.16 & 8.84 \\
\hline \multicolumn{15}{|l|}{ Gender } \\
\hline Women $(n=30)$ & $\%$ & 12.67 & 11.08 & 11.33 & 11.58 & 11.08 & 12.33 & 11.13 & 10.50 & 15.33 & 12.94 & 13.75 & 15.50 & 11.00 \\
\hline Men $(n=43)$ & $\%$ & 9.88 & 8.49 & 7.09 & 6.63 & 8.08 & 8.26 & 8.87 & 8.45 & 8.60 & 8.10 & 7.84 & 8.14 & 7.34 \\
\hline \multicolumn{15}{|c|}{ Education } \\
\hline Non-university $(n=20)$ & $\%$ & 13.57 & 11.25 & 12.14 & 12.14 & 11.61 & 13.57 & 10.36 & 9.64 & 15.75 & 13.57 & 14.64 & 16.57 & 10.71 \\
\hline University $(n=53)$ & $\%$ & 10.42 & 9.15 & 8.05 & 7.84 & 8.77 & 8.98 & 9.66 & 9.32 & 9.72 & 9.32 & 9.22 & 9.41 & 8.39 \\
\hline
\end{tabular}

simple correlation coefficients are calculated. Only gender and education have significant correlation coefficients (at the 5\% significance level) with certification premiums. Hence, premiums for each product and price are calculated separately by gender and two education levels, university and non-university. The results are presented in Table 3 . The premium for wood products women are willing to pay ranges from $10.5 \%$ to $15.5 \%$ while for men the range is $6.63 \%$ to $9.88 \%$. The differences in premiums by women and men are statistically significant at $5 \%$ significance level for all paper products, flooring priced at $\$ 6$ per square foot, and wood furniture priced at the $\$ 500$ and $\$ 1000$ levels. The range of premiums for those with a high school education is $9.64 \%$ to $16.57 \%$, and for those with a university education $7.84 \%$ to $10.42 \%$. The premiums by these two groups are, however, not statistically different at $5 \%$ significance level for any product and price combination. The correlation analysis indicates that gender and education are only two possible demographic and social variables that may explain some of the variation in certification premium. Hence, certification premiums were regressed over dummy variables corresponding to gender and education to find out the degree of variation in certification premium explained by these two variables. The values of adjusted $R^{2}$ are very low for all the equations; and the maximum value of adjusted $\mathrm{R}^{2}$ is 0.13 (for a table priced at $\$ 1000$ ). Only in the cases of a wooden table priced at $\$ 1000$, high quality paper (priced at $\$ 4$ ), and letterhead paper (priced at \$6), are the coefficients of gender variable different from zero at the $5 \%$ significance level. The coefficients of education variable are not different from zero in any of the equations. Hence, the gender variable explains a very small variation in only selected items. The observation that the socioeconomic and demographic variables are not good explanatory variables of willingness to pay a premium for certified wood products is similar to the previous observations of Polonsky and Wimsatt (1995).

\section{Consumer segments and premium for certified forest products}

Next, to find out consumer segments who are willing to pay a certification premium, the empirical technique, cluster analysis, is used (Anderberg 1973). In this study, clustering is done on the basis of responses to twelve questions related to membership of environmental groups, environmental problems, and environmental labels. A five-cluster solution is chosen on the basis of the minimum number of clusters that give the best combination of homogeneity within clusters, and heterogeneity across clusters (Punj and Stewart 1983). The results for the five-cluster solution are given in Table 4 including the sample sizes, cluster means, and results from an ANOVA test of differences between cluster means. ANOVA analysis indicates that mean values for every dimension for cluster 1 are different from mean values for cluster 5 . There is no such marked difference for any other combination of clusters. The specific differences among means of different clusters are given in Table 4.

Next, willingness to pay a certification premium for each product and price was compared across these clusters. The results of this analysis are presented in Table 5. The outcome of this analysis confirms the results of the cluster analysis given in Table 4 . The ranking from the highest premium to the lowest premium (for most products and prices) is as follows: cluster 1 , cluster 3 , cluster 2 , cluster 4 , and cluster 5 . Therefore, the respondents in cluster 1 who indicated that they are most environmentally concerned and to whom certification is the most important in the production of wood products is the group most likely to pay the highest premiums. Cluster 5 respondents, the least environmentally concerned group, are willing to pay the lowest premium. To check the demographic and socioeconomic variations among these clusters, ANOVA analysis was performed. No statistically significant difference $(5 \%)$ was observed for any variable across any two clusters. Hence, environmental preferences of consumers and not the socioeconomic or demographic variables are the main determinants of consumers' willingness to pay a premium for certified wood products.

\section{Primary producer and re-manufacturer survey}

The response rate of primary producers was $31.25 \%$. The respondent primary producers consist of 30 companies ranging in annual production from 1 million to 1.5 billion feet board measure (fbm) (average of $70687179 \mathrm{fbm}$ ) and in employment from 2 to 4200 employees (average of 294). The survey results are given in Table 6 . The annual production capacity of the 6 companies that indicated willingness to pay a premium ranges from 1 to 9 million $\mathrm{fbm}$. None of these companies had any orders for certified products. All companies have indicated their willingness to pay a premium would increase if the premium could be passed on to their consumers. Four of the six companies produce value-added speciality wood products, e.g., cedar shakes, fencing, log kits, and deal, at most, with three tree species. All four companies are able to separate certified from non-certified products on site and are interested in a chainof-custody tracking system. One of the four companies has exported products to the U.S. and to Europe. The other two companies that indicated willingness to pay a premium produce dimension lumber. Neither of these companies is able to separate certified wood on site nor are they interested in a chain-of- 
Table 4. Results of cluster analysis* based on questions regarding membership in environmental group, environmental concerns, environmental information and labelling. (Section 2 of the survey).

\begin{tabular}{|c|c|c|c|c|c|c|c|}
\hline \multirow[b]{2}{*}{ Questions } & \multicolumn{5}{|c|}{ Cluster means } & \multirow[b]{2}{*}{$\begin{array}{l}\text { ANOVA } \\
F \text {-stat }\end{array}$} & \multirow[b]{2}{*}{$P$-value } \\
\hline & $\begin{array}{c}\text { Cluster } 1 \\
n=29\end{array}$ & $\begin{array}{c}\text { Cluster } 2 \\
n=6\end{array}$ & $\underset{n=17}{\text { Cluster } 3}$ & $\begin{array}{c}\text { Cluster } 4 \\
n=10\end{array}$ & $\underset{n=11}{\text { Cluster } 5}$ & & \\
\hline 2a) Member of an environmental group & 0.28 & 0.00 & 0.24 & 0.10 & 0.00 & 1.63 & 0.12 \\
\hline \multicolumn{8}{|l|}{ Environmental Concerns (2b) } \\
\hline $\begin{array}{l}\text { a) Importance of environmental problems } \\
\text { is exaggerate }\end{array}$ & 4.55 & 3.00 & 4.47 & 2.10 & 2.18 & $34.46^{1}$ & 0.00 \\
\hline $\begin{array}{l}\text { b) I do what is good for the environment } \\
\text { even if it costs more }\end{array}$ & 1.97 & 1.33 & 1.88 & 1.70 & 2.64 & $3.25^{2}$ & 0.02 \\
\hline $\begin{array}{l}\text { c) The state of the environment in the future } \\
\text { worries me }\end{array}$ & 1.21 & 1.00 & 1.53 & 1.50 & 3.45 & $31.25^{3}$ & 0.00 \\
\hline $\begin{array}{l}\text { d) TV broadcasts about environmental problems } \\
\text { make me angry }\end{array}$ & 1.76 & 1.17 & 1.88 & 2.10 & 3.27 & $8.33^{4}$ & 0.00 \\
\hline $\begin{array}{l}\text { e) Environmental problems are less urgent than } \\
\text { claimed }\end{array}$ & 4.52 & 1.83 & 4.59 & 4.40 & 3.00 & $20.62^{5}$ & 0.00 \\
\hline f) We are headed for an environmental catastrophe & 1.52 & 1.83 & 2.76 & 1.80 & 4.00 & $19.83^{6}$ & 0.00 \\
\hline \multicolumn{8}{|l|}{ Environmental Information and Labelling (2c) } \\
\hline $\begin{array}{l}\text { a) There is sufficient info on environ. } \\
\text { friendliness on products }\end{array}$ & 4.24 & 2.33 & 2.65 & 3.40 & 3.18 & $9.55^{7}$ & 0.00 \\
\hline b) Environmental labels are not trustworthy & 1.76 & 1.83 & 3.29 & 2.80 & 2.82 & $12.25^{8}$ & 0.00 \\
\hline c) The variety of labels is confusing & 2.17 & 1.67 & 3.47 & 2.30 & 2.45 & $6.66^{9}$ & 0.00 \\
\hline $\begin{array}{l}\text { d) Environmental information on products } \\
\text { is clear and easy to understand }\end{array}$ & 3.76 & 2.50 & 2.47 & 3.70 & 2.73 & $11.24^{10}$ & 0.00 \\
\hline $\begin{array}{l}\text { e) Environmental information is most } \\
\text { important aspect of production info }\end{array}$ & 1.48 & 1.83 & 2.41 & 2.40 & 3.45 & $14.00^{11}$ & 0.00 \\
\hline
\end{tabular}

*Cluster 1 differs from 5 in all cases.

${ }^{1}$ Cluster 1 differs from 2, 4,; cluster 2 differs from 5 ; cluster 3 differs from 2, 4, 5 .

${ }^{2}$ Cluster 5 differs from $2,3,4$.

${ }^{3}$ Cluster 5 differs form 2,3,4.

${ }^{4}$ Cluster 2 differs from 4 ; cluster 5 differs from 2, 3, 4 .

${ }^{5}$ Cluster 1 differs from 2; cluster 2 differs from 5 ; cluster 3 differs from 2, 5; cluster 4 differs from 2,5.

${ }^{6}$ Cluster 3 differs from $1,2,4,5$; cluster 5 differs from 2, 4 .

${ }^{7}$ Cluster 1 differs from 2, 3, 4; cluster 2 differs from 4 .

${ }^{8}$ Cluster 1 differs from 3,4 ; cluster 2 differs from $3,4,5$.

${ }^{9}$ Cluster 3 differs from $1,2,4,5$.

${ }^{10}$ Cluster 1 differs from 2, 3; cluster 4 differs from 2, 3, 5.

${ }^{11}$ Cluster 1 differs from 3,4 ; cluster 5 differs from $2,3,4$.

custody tracking system. Both companies have exported products to the U.S.

The response rate of re-manufacturers (or secondary manufacturers) was $36 \%$. The respondent fourteen re-manufacturers range in annual production from 200000 to $60000000 \mathrm{fbm}$, and the employment level ranges from 4 to 250 with an average of 46 employees. Of the two companies willing to pay a premium, one company (200 $000 \mathrm{fbm}$ annual production) produces only one type of value-added product (mouldings) with only one species (oak). This company is able to separate certified and non-certified products on site and is interested in a chain-of-custody tracking system. The second company is much larger (14000 000 annual fbm), produces only one product (fencing) with a few tree species, and is able to separate certified and non-certified products but is not interested in a chain-of-custody tracking system as an additional tracking system is seen as being too confusing. The other four companies that are able to separate certified and non-certified products are not willing to pay a premium. These companies produce such products as futons, trusses, and turnings with one or two species (mostly oak and spruce). Two of these companies have indicated that they are interested in a chain-of-custody tracking system.

Some general similarities can be drawn from the responses of the primary producer and secondary manufacturer.
First, few companies are familiar with the FSC while more are familiar with the CSA. As there are no certified forests in Canada presently, no companies purchase certified wood from Canada. A couple of companies have indicated that they have purchased certified products from the U.S., but they do not pay a premium for these products. Almost all companies are willing to buy certified products but few companies are willing to pay a premium for them. The awareness of forest certification issues is higher in companies that export products to the U.S. or to Europe. All companies surveyed have indicated they would be willing to purchase wood/wood products directly from a certified forest operator. It has been suggested that buying direct from certified companies, and thus leaving out the "middleman," could counteract the effect of having to charge a premium. For example, Portico of Costa Rica sells its value- added products directly to Home Depot (Eisen 1994). Reducing the number of intermediaries may also mean the consumer will pay the same price for certified timber as for non-certified timber. The incremental revenue can be captured by the producer. Therefore, this provides an incentive rather than a price increase on the final product.

It is clear that the awareness of certification and market opportunities within the forest industry in Ontario is low. In the three states of California, Oregon and Washington in the US, Mater (1995) found that: (i) an overall awareness level of $62 \%$ for 
Table 5. Consumers willingness to pay a premium for certified forest products across clusters ${ }^{1}$

\begin{tabular}{|c|c|c|c|c|c|c|c|c|}
\hline \multicolumn{2}{|l|}{ Products } & \multirow{2}{*}{$\begin{array}{c}\text { Cluster } \mathbf{1} \\
\boldsymbol{n}=\mathbf{2 9}\end{array}$} & \multirow{2}{*}{$\begin{array}{c}\begin{array}{c}\text { Cluster } 2 \\
\mathbf{n = 6}\end{array} \\
9.17\end{array}$} & \multirow{2}{*}{$\begin{array}{c}\begin{array}{c}\text { Cluster } \mathbf{3} \\
\mathbf{n}=\mathbf{1 7}\end{array} \\
11.47\end{array}$} & \multirow{2}{*}{$\begin{array}{c}\begin{array}{c}\text { Cluster } \mathbf{4} \\
\boldsymbol{n}=\mathbf{1 0}\end{array} \\
9.50\end{array}$} & \multirow{2}{*}{$\begin{array}{c}\begin{array}{c}\text { Cluster } \mathbf{5} \\
\boldsymbol{n}=\mathbf{1 1}\end{array} \\
6.82\end{array}$} & \multirow{2}{*}{$\begin{array}{c}\underset{F \text {-stat }}{\text { ANOVA }} \\
2.16\end{array}$} & \multirow{2}{*}{$\begin{array}{c}P \text {-value } \\
0.08\end{array}$} \\
\hline Wood table & $\$ 100$ & & & & & & & \\
\hline & $\$ 200$ & 11.47 & 9.17 & 10.00 & 7.50 & 5.91 & 2.29 & 0.07 \\
\hline & $\$ 500$ & 10.86 & 9.17 & 9.12 & 6.50 & 5.00 & 2.36 & 0.06 \\
\hline & $\$ 1000$ & 11.20 & 9.17 & 8.24 & 6.00 & 4.77 & $2.54^{3}$ & 0.05 \\
\hline \multicolumn{9}{|c|}{ Flooring (per sq ft) } \\
\hline & $\$ 4$ & 11.64 & 9.17 & 9.27 & 8.00 & 4.55 & 2.72 & 0.04 \\
\hline & $\$ 6$ & 11.72 & 9.17 & 10.29 & 8.00 & 6.34 & 1.33 & 0.27 \\
\hline \multicolumn{9}{|c|}{ Lumber (2×4) } \\
\hline & $\$ 1.5$ & 11.55 & 9.17 & 10.59 & 8.00 & 5.91 & $2.11^{4}$ & 0.09 \\
\hline & $\$ 3$ & 10.86 & 9.17 & 10.00 & 8.00 & 5.91 & 1.70 & 0.16 \\
\hline \multicolumn{9}{|c|}{ Paper products } \\
\hline & $\$ 2$ & 15.17 & 9.17 & 12.06 & 9.00 & 3.65 & 1.83 & 0.13 \\
\hline & $\$ 6$ & 12.07 & 9.17 & 12.36 & 8.50 & 3.64 & $2.69^{5}$ & 0.04 \\
\hline & $\$ 10$ & 12.93 & 9.17 & 11.74 & 8.50 & 3.18 & $2.99^{6}$ & 0.02 \\
\hline & $\$ 1$ & 13.97 & 9.17 & 12.65 & 8.50 & 5.00 & 1.18 & 0.33 \\
\hline & $\$ 20$ & 9.93 & 9.17 & 11.50 & 8.50 & 2.27 & $3.80^{7}$ & 0.01 \\
\hline
\end{tabular}

${ }^{1}$ Cluster 1 differs from 5 in all cases.

${ }^{2} \mathrm{~A}$ one-way ANOVA was performed to test the hypothesis of no difference between cluster means.

${ }^{3}$ Cluster 1 differs from 4.

${ }^{4}$ Cluster 3 differs from 5 .

${ }^{5}$ Cluster 3 differs from 5.

${ }^{6}$ Cluster 3 differs from 5 .

${ }^{7}$ Cluster 5 differs from 2, 3, 4 .

Table 6. Survey results of Ontario primary producers and remanufacturers of forest products.

\begin{tabular}{|c|c|c|c|c|}
\hline \multirow[b]{2}{*}{ Questions } & \multicolumn{2}{|c|}{$\begin{array}{c}\text { Primary Producers } \\
\text { whose response is } \\
\text { yes }(n=30)\end{array}$} & \multicolumn{2}{|c|}{$\begin{array}{c}\text { Remanufacturers } \\
\text { whose response is } \\
\text { yes }(n=14)\end{array}$} \\
\hline & Number & Percentage & Number & Percentage \\
\hline Heard of "Forest Management certification": & 21 & $(70 \%)$ & 6 & $(43 \%)$ \\
\hline Familiar with the Forest Stewarship Council: & 11 & $(37 \%)$ & 2 & $(14 \%)$ \\
\hline Familiar with the CSA: & 21 & $(70 \%)$ & 11 & $(78 \%)$ \\
\hline Have had requests for certified products: & 1 & $(3 \%)$ & 0 & $(0 \%)$ \\
\hline Presently purchase products from certified companies: & 4 & $(13 \%)$ & 2 & $(14 \%)$ \\
\hline Willingness to buy certified products: & 26 & $(87 \%)$ & 14 & $(100 \%)$ \\
\hline Willingness to pay a premium: & 6 & $(20 \%)$ & 2 & $(14 \%)$ \\
\hline Would premium payed increase if passed on to the consumer: & 14 & $(47 \%)$ & 8 & $(57 \%)$ \\
\hline Ablility to separate certified from non-certified wood on site: & 6 & $(20 \%)$ & 6 & $(43 \%)$ \\
\hline Would separation require added cost: & 25 & $(83 \%)$ & 12 & $(86 \%)$ \\
\hline Interested in chain of custody tracking: & 6 & $(20 \%)$ & 3 & $(21 \%)$ \\
\hline Presently sell certified products: & 0 & $(0 \%)$ & 1 & $(7 \%)$ \\
\hline Willing to buy direct: & & & 13 & $(93 \%)$ \\
\hline Premium Question Responses & Premium & Respondents & Premium & Respondents \\
\hline \multirow[t]{3}{*}{ Willing to pay a premium: } & $0 \%$ & 24 & $0 \%$ & 12 \\
\hline & $5 \%$ & 3 & $5 \%$ & 2 \\
\hline & $10 \%$ & 3 & $10 \%$ & 0 \\
\hline
\end{tabular}

producers and manufacturers of wood products; (ii) $25 \%$ of 23 primary producers and $51 \%$ of 123 secondary manufacturers are willing to pay a $10 \%$ premium for certified wood and wood products; and, (iii) $50 \%$ of primary producers and $70 \%$ of secondary manufacturers are able to separate certified products on site and are interested in using a simple chain-of-custody tracking system. These numbers indicate that, presently, the market atmosphere for certification in Ontario is quite different from that seen in the northwestern U.S.

\section{Conclusions and Recommendations}

We hope that this study will provide an impetus to further research on certification of forest products in Canada. The out- come of this study provides an information base for forest-product companies, certification agencies like the FSC and the CSA, and policy-makers, in making strategic forest management and product marketing decisions. Further studies, such as the present study, are needed to examine the potential of certification within the whole of Canada.

This study indicates that consumers in Ontario are environmentally conscious and, all else being equal, (e.g., price and quality), would prefer to purchase certified forest products rather than non-certified forest products. The modal response with respect to almost all products is that consumers are willing to incur a $10 \%$ premium for certified forest products; however, the actual premium varies depending on the type of product. 
Lower priced furniture and lumber products could command a higher premium than higher priced products. Companies interested in pursuing certification will likely find markets for their products but demand will, most likely, be fuelled by their own initiatives in developing those markets. The present study indicates that the consumer segment that would most likely pay the highest premiums for certified forest products is independent of demographic and socioeconomic variables, but depends on environmental awareness. Hence, companies can enhance this market by appropriate marketing strategies aimed to increase environmental awareness through environmental education programs.

Awareness and acceptance of certification is low among key players in the forest industry in Ontario (i.e., primary producers and remanufacturers). This disconnectivity in the forest industry may become an obstacle for the distribution of certified products in the future from the forest to the manufacturer and to the consumer. Special attention should be given to this linkage either by companies seeking certification or by the certification organizations themselves. An educational campaign to increase awareness, demand, and the economic advantage of certification should be the first step in the development process of certification in Canada. Lessons can be learned through case studies of forest certification in other areas such as the U.S. and Europe.

\section{Acknowledgements}

We are extremely thankful to Dr. Peter Schwarzbauer, Department of Forestry Sector Socioeconomics, University of Agricultural Sciences, Vienna, Austria, for providing us a copy of the consumer survey for a European Union project on forest certification. We are thankful to Marcelo Levy, Coordinator, Forest Stewardship Council, Canadian Initiative, for supporting the project. The financial help received from the Natural Sciences and Engineering Research Council of Canada through Grant No. 203032-90RGPN is also gratefully acknowledged.

\section{References}

Anderberg, M.R. 1973. Cluster Analysis for Applications. Academic Press, New York.

Chase, D. 1991. The green revolution: $P \& G$ gets top marks in AA survey. Advert. Age 62: 8-10.

Coddington, W. 1993. Environmental Marketing. McGraw-Hill, Inc., New York.
Dillman, D.A. 1978. Mail and Telephone Surveys - The Total Design Method. John Wiley and Sons, New York.

Eisen, M. 1994. What marketers want from timber certification. Proceedings from Conference on Timber Certification: Implications for Tropical Forest Management. Yale School of Forestry and Environmental Studies, New Haven, CT.

Elliott, C. and A. Hackman. 1996. Current Issues in Forest Certification in Canada. WWF Canada, Toronto, Ont.

Field, B.C. 1994. Environmental Economics: An Introduction. McGraw-Hill, Inc. New York.

Kirkpatrick, D. 1990. Environmentalism: the new crusade. Fortune 121: 44-51.

Leslie, J. 1990. Green about the tills: markets discover the eco-consumer. Manag. Rev. 79: 24-29.

Lloyd, I. 1993. Wood producers face green marketing era. Wood Tech. 120: 34-36.

Lyke, J. 1994. Forest product certification revisited: an update. J. For. 94: 16-20.

Mater, J. 1995. Certified forest products: Building tomorrow's market today. J. For. 93: 36-37.

Mitchell, P.C. and R.T. Carson. 1989. Using surveys to value public goods: the contingent value method. Resources for the Future, Washington, D.C.

Ozanne, L.K. and P.M. Smith. 1995. Wooden household furniture: does the environment matter to consumers?. Unpubl.

Ozanne, L.K. and R.P. Vlosky. 1997. Willingness to pay for environmentally certified wood products: a consumer perspective. For. Prod. J. 47: 39-48.

Polonsky, M.J. and A.T. Wimsatt. 1995. Environmental Marketing: Strategies, Practice, Theory and Research. The Hawarth Pres Inc., Binghamton, New York.

Punj, G. and D.W. Stewart. 1983. Cluster analysis in marketing research: Review and suggestions for application. J. Market. Res. 20: 134-148.

Shrum, L.J., J.A. McCarty and T.M. Lowrey. 1995. Buyer characteristics of the green consumers and their implications for advertising strategy. Jour. Advert. 121: 71-82.

Upton, C. and S. Bass. 1996. The Forest Certification Handbook. St. Lucie Press, Delray Beach, Fl.

Winterhalter, D. and D. Cassens. 1993. Telling the sustainable forest from the trees. Furniture Design and Manufacturing. August: 101-106. World Wide Fund for Nature. 1996. The WWF 1995 group, the full story. WWF-UK, Godalming, Surrey, U.K.

Zimmer, D. 1995. Eco-labelling gets a bad name. Pulp \& Paper Int. 37: 17.

Zinkhan, G.M. and L. Carlson. 1995. Green advertising and the reluctant consumer. Journ. Advert. 121: 27-29. 


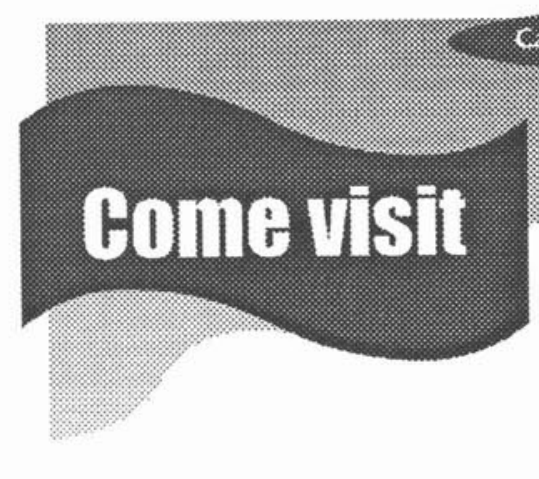

\title{
CIF/IFC Web site \\ - http://www.cif-ifc.org
}

\section{A VOICE FOR THE FOREST PRACTITIONER}

\section{FOR OVER 90 YEARS}

\author{
- Forestry Forum - an open - National Award Information \\ discussion group on forestry \\ issues that interest you \\ - Forestry Chronicle abstracts \\ - Apply for membership \\ - Subscription rates / \\ Advertising rates
}

- Section links

- Links to RPFs / Technician/

- NEW - For members only technologists Forestry Update on Line/to subscribe send your email address to cif@cif-ifc. org - with subscribe in the subject line./

- Comprehensive Conferences/ Meeting dates

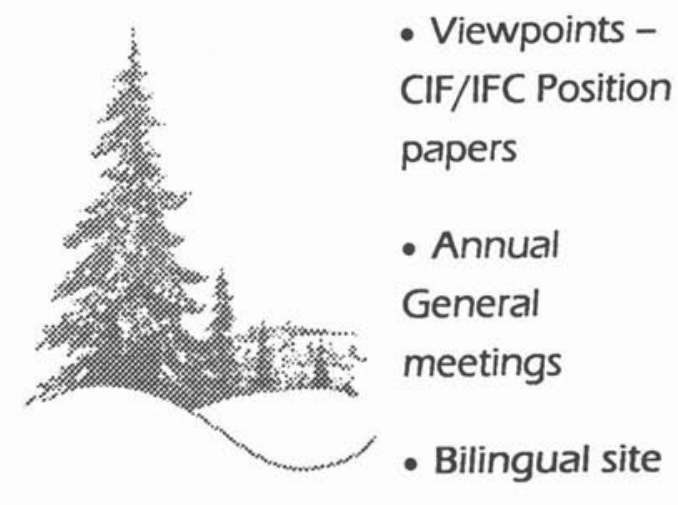
- Viewpoints CIF/IFC Position papers listing

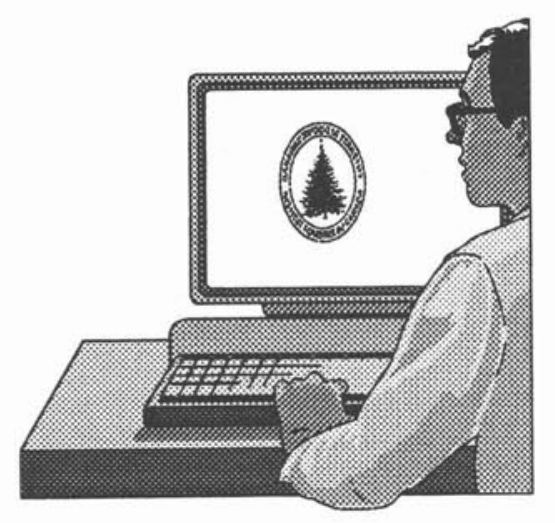

Canadian Institute of Forestry/ Institut forestier du Canada

151 Slater Street, Suite 606 Ottawa, Ontario K1P $5 \mathrm{H} 3$ Tel (613)234-2242 Fax (613)234-6181 Email cif@cif-ifc.org 